\title{
Nanosized $\mathrm{TiO}_{2}-\mathrm{A}$ promising catalyst for the aldol condensation of furfural with acetone in biomass upgrading
}

\author{
Dong Nguyen Thanh ${ }^{a}$, Oleg Kikhtyanin ${ }^{a}$, Ruben Ramos ${ }^{a}$, Maadhav Kothari ${ }^{a}$, \\ Pavel Ulbrich ${ }^{\mathrm{b}}$, Tasnim Munshi ${ }^{\mathrm{c}}$, David Kubička ${ }^{\mathrm{a}, *}$ \\ a Research Institute of Inorganic Chemistry, RENTECH-UniCRE, Chempark Litvínov, Záluží, Litvínov 43670, Czech Republic \\ b Institute of Chemical Technology, Technická 5, 166 28, Prague 6, Czech Republic \\ ' School of Chemistry, College of Science, University of Lincoln, Brayford Pool, Lincoln, Lincolnshire, LN6 7TS, United Kingdom
}

\section{A R T I C L E I N F O}

\section{Article history:}

Received 30 July 2015

Received in revised form 16 October 2015

Accepted 23 November 2015

Available online $\mathrm{xxx}$

\section{Keywords:}

Aldol condensation

Furfural

Acetone

Titanium oxide

Calcination

Biofuel

\begin{abstract}
A B S T R A C T
Nanosized $\mathrm{TiO}_{2}$ catalyst was successfully prepared by a simple green procedure and used in liquid phase aldol condensation of furfural with acetone, a key step in bio-fuel processing. In order to determine the effect of calcination temperature on catalytic properties of $\mathrm{TiO}_{2}$, the as-prepared $\mathrm{TiO}_{2}$ and calcined $\mathrm{TiO}_{2}\left(150-900^{\circ} \mathrm{C}\right)$ were studied by XRD, BET, TPD- $\mathrm{CO}_{2} / \mathrm{NH}_{3}$, TGA/DTG and FTIR evaluation. The catalytic performance of $\mathrm{TiO}_{2}$ samples in aldol condensation of furfural with acetone was evaluated and compared with that of $\mathrm{Mg}-\mathrm{Al}$ hydrotalcites and a BEA zeolite. These experiments showed that uncalcined $\mathrm{TiO}_{2}$ possessed reasonable activity in aldol condensation of furfural to acetone and resulted in commonly produced condensation products. The observed catalytic behavior of $\mathrm{TiO}_{2}$ could be competitive with that reported for other inorganic solids. The calcination of $\mathrm{TiO}_{2}$ resulted, however, in a decrease in its catalytic activity due to extensive dehydration and surface dehydroxylation as well as due to changes of textural properties resulting in a decrease in the amount of accessible active sites. Thanks to its advanced properties, nanosized $\mathrm{TiO}_{2}$ is a promising catalyst for aldol condensation of furfural with acetone and could broaden possibilities for optimizing conditions for bio-fuel production.
\end{abstract}

(c) 2016 Elsevier B.V. All rights reserved.

\section{Introduction}

The world's energy system needs to be adapted to a more sustainable one, based on a diverse mix of energy resources, addressing the pressing challenges of energy security supply and climate change [1]. Nowadays, there is a change in the biomass energy uses from traditional and non-commercial ones, such as simple open combustion to produce heat, to modern ones, such as advanced processes to produce electricity and bio-fuels integrated in food and biomaterials industries [2]. The technical and economic potentials of biomass are higher than the current world energy consumption $[1,2]$, thus, the main challenge is in its viable and sustainable use. The most abundant biomass resource is lignocellulosic biomass consisting of cellulose, hemicellulose and lignin [3]. Some other materials such as ash, proteins, pectin, etc. are also found in the lignocellulosic biomass in different proportion depending on the biomass source and origin [4]. In addition to dedicated biomassfor-energy plantations, waste biomass holds enormous potential with a high degree of sustainability. These waste materials can be

\footnotetext{
* Corresponding author. Fax: +420 476768476.

E-mail address: david.kubicka@vscht.cz (D. Kubička).
}

categorized based on their source such as industrial waste (sawdust, paper mill discards, food industry residues, etc.), forestry waste (branches, hard and soft wood residues, etc.), agricultural residues (straw, stover, peelings, cobs, stalks, nutshells, non-food seeds, etc.), domestic waste (kitchen wastes, sewage, waste papers, etc.), and municipal solid waste [4,5]. These materials are considered as one of the most promising bio-based feedstocks for the production of fuels and other chemical products as they are not in direct competition with food crops, fodder, and natural habitat [6].

Furanic compounds (e.g. furfural, 5-hydroxymethlyfurfural) and acetone are readily available chemicals, which can be produced by the hydrolysis of biomass [7]. Additionally, acetone is available as a by-product in phenol production. Aldehydes and ketones can react by aldol condensation and result in the production of higher added value products from simple and cheap ones. In order to exploit the full potential of furfural as a platform chemical, its transformation by aldol condensation with acetone followed by hydrogenation/deoxygenation has been proposed to afford hydrocarbons, namely $C_{8}$ and $C_{13}$ alkanes [8] (see Scheme 1). Aldol condensation proceeds in the presence of either basic or acidic catalysts $[9,10]$. The most effective industrially available methods rely on using liquid bases $\left(\mathrm{NaOH}\right.$ or $\mathrm{KOH}$ ) or mineral acids (e.g. $\mathrm{H}_{2} \mathrm{SO}_{4}$ ) as catalysts [9]. However, these catalysts pose a major environmen- 


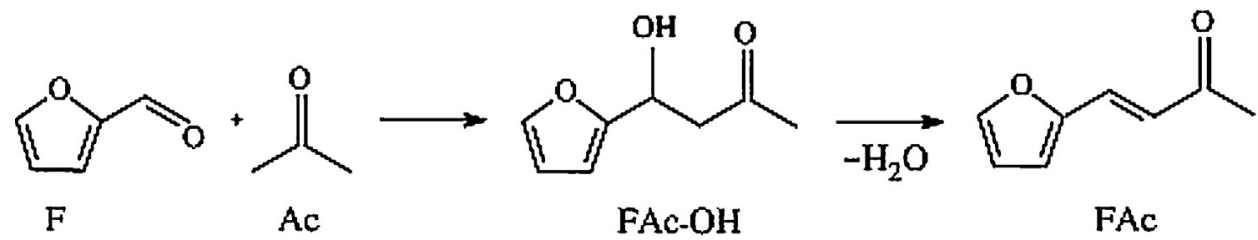<smiles>CC(=O)/C=C/c1ccco1</smiles>

Scheme 1. Reaction scheme of aldol condensation of furfural with acetone.

tal threat due to waste water production and equipment corrosion. In addition, solid catalysts with acid-base character are recognized as a promising alternative to homogeneous catalysts for aldol condensation of furfural with acetone. Among solid catalysts, double layered hydroxides (hydrotalcites) with basic character are considered as the most promising catalysts for this reaction [8,11-15]. The essential disadvantages of such basic catalysts are their high sensitivity to ambient $\mathrm{CO}_{2}$, which transforms them into catalytically inactive carbonates, and the lack of reliable methods for recovering their catalytic properties after regeneration [16-18]. Recently, zeolites have been reported as catalysts for aldol condensation of furfural with acetone [19]. It was shown that by using zeolites the disadvantages of basic catalysts i.e. susceptibility to $\mathrm{CO}_{2}$ and poor regenerability could be avoided. On the other hand, their activity in aldol condensation of furfural with acetone is lower than that of hydrotalcites. Moreover, they are rapidly deactivated due to coke formation during the reaction [19]. Therefore, along with the optimization of the properties of the solid basic catalysts, attention is currently being focused on alternative solid catalysts for aldol condensation of furfural with acetone.

Titanium dioxide $\left(\mathrm{TiO}_{2}\right)$ is one of the most common materials in our daily life; in addition to its application in water and air purification and in pigments, it has emerged as an excellent photocatalyst for environmental purification applications [20]. $\mathrm{TiO}_{2}$ exists mainly in three different crystalline phases: rutile (tetragonal), anatase (tetragonal) and brookite (orthorombic), out of which rutile is the most thermodynamically stable phase [21]. The main advantages of $\mathrm{TiO}_{2}$ are its high chemical stability when exposed to acidic and basic compounds, nontoxicity, relatively low cost and high oxidizing power, which make it a competitive candidate for many photocatalytical applications [22].

To the best of our knowledge, no research study has examined the reaction of aldol condensation of furfural with acetone over nanosized titanium oxides up to date. The aim of this work is to investigate a reusable solid $\mathrm{TiO}_{2}$ catalyst suitable for aqueous phase environment having high activity in aldol condensation. The research is focused on the following key objectives: (1) preparation of $\mathrm{TiO}_{2}$ catalysts by co-precipitation from environmentally friendly and low-cost raw materials; (2) in-depth characterization of the prepared materials; and finally (3) a description of the effect of pretreatment temperature of the $\mathrm{TiO}_{2}$ catalysts on their activity and selectivity in aldol condensation of furfural with acetone.

\section{Experimental and materials}

\subsection{Materials}

All chemicals were reagent grade and used as received. Titanium (IV) oxysulfate $\mathrm{TiOSO}_{4}$ (Precheza a.s.) and urea $\mathrm{CH}_{4} \mathrm{~N}_{2} \mathrm{O}$ (Lach:Ner, p.a.) were used for synthesis of $\mathrm{TiO}_{2}$. $\mathrm{Mg}-\mathrm{Al}$ hydrotalcites (HTC) with $\mathrm{Mg}$ to $\mathrm{Al}$ molar ratio of 3 was prepared according to [23]. BEA zeolite $(\mathrm{Si} / \mathrm{Al}=12.5)$ was received from Zeolyst Int. (CP 814E). Commercial sample $\mathrm{TiO}_{2}$ P25 (Aeroxide ${ }^{\circledR}$ P25, Titanium (IV) oxide nanopowder) was obtained from Sigma-Aldrich. Acetone (Lach:Ner, p.a.) and furfural (Acros Organics, 99\%) used for the catalytic experiments were dried using a $\mathrm{CaA}$ molecular sieve prior to the experiments.

\section{2. $\mathrm{TiO}_{2}$ synthesis}

The nanosized $\mathrm{TiO}_{2}$ was prepared by hydrolysis of $\mathrm{TiOSO}_{4}$ in aqueous solutions using urea as the precipitation agent. In a typical process, $\mathrm{TiOSO}_{4}$ was dissolved in distilled water. The pellucid solution was heated to $95^{\circ} \mathrm{C}$ for $1 \mathrm{~h}$, then mixed with urea and continuously heated at $100^{\circ} \mathrm{C}$ for $5 \mathrm{~h}$ under stirring until pH reached 7.02. The formed precipitate was decanted, filtered and dried at $100^{\circ} \mathrm{C}$ and the obtained white powder was denoted as "as-prepared $\mathrm{TiO}_{2}$ " sample. In order to study the effect of calcination temperature on the catalytic performance, the as-prepared $\mathrm{TiO}_{2}$ sample was calcined in air at different temperatures in the range $150-900{ }^{\circ} \mathrm{C}$ for $2 \mathrm{~h}$. All the samples were denoted as " $\mathrm{TiO}_{2}-T$ ", where $T$ represents the calcination temperature.

\subsection{Physico-chemical characterization}

The catalysts were characterized by several techniques to assess their structure, composition, surface area and pore volume. The crystallographic structures of $\mathrm{TiO}_{2}$ catalysts were determined by X-ray powder diffraction using a Philips MPD 1880, working with the $\mathrm{Cu}-\mathrm{K} \alpha$ line $(\lambda=0.154 \mathrm{~nm})$ in the $2 \theta$ range of $5-70^{\circ}$ at a scanning rate of $2 \theta$ of $2.4^{\circ} / \mathrm{min}$. The XRD crystal size was calculated by using Scherrer equation as follows [24]:

$\mathrm{D}=\frac{k \lambda}{\beta \cos \theta}$

where $k$ is a constant equal to $0.89 ; \lambda$ is the X-ray wavelength, $\beta$ is the full width at half maximum intensity (FWHM) and $\theta$ is the half diffraction angle. The phase composition of the samples was calculated by using the following equation:

Rutile phase $(\%)=\frac{100}{[1+0.8(\mathrm{IA} / \mathrm{IR})]}$

where IA and IR are integrated intensities of the anatase (1 01 ) and rutile (1 110$)$ diffraction peaks, respectively.

Chemical analysis of as-prepared $\mathrm{TiO}_{2}$ sample was performed with WDXRF spectrometer Philips PW 1404 with rhodium tube. The measurement was aimed to control the content of residual sulfate groups on $\mathrm{TiO}_{2}$ surface after hydrolysis and washing stages. 
A full isotherm of each sample was obtained under standard conditions at $77 \mathrm{~K}$ with nitrogen gas as the adsorbate using an Autosorb-IQ (Quantachrome). Each sample was outgassed under vacuum for $4 \mathrm{~h}$ at a lower temperature than the pre-prepared material. The specific surface area was calculated by applying the Brunauer-Emmett-Teller (BET) equation within the range of $0.05-0.2 \mathrm{P} / \mathrm{P0}$. The overall pore volume and the average pore size were determined by the BJH method to the adsorption branch.

FTIR spectra were collected using a Thermo Scientific Nicolet iS10 FT-IR Spectrometer using the ATR technique. The IR spectra of $\mathrm{TiO}_{2}$ samples were obtained as dry samples. All IR measurements were carried out at room temperature.

Thermogravimetric analysis (TGA/DTG) of the dried $\mathrm{TiO}_{2}$ catalysts was performed using a TA Instruments TGA Discovery series equipment operated at a heating ramp of $10^{\circ} \mathrm{C} / \mathrm{min}$ from room temperature to $900^{\circ} \mathrm{C}$ in flowing nitrogen $(20 \mathrm{~mL} / \mathrm{min}$, Linde 3.0$)$. Approximately $15 \mathrm{mg}$ of sample was heated in an open alumina crucible.

Analytical measurements of temperature programmed desorption (TPD) were performed in order to evaluate the acidity and basicity of the synthesized $\mathrm{TiO}_{2}$ samples, as well as some reference materials (Beta zeolite, commercial $\mathrm{TiO}_{2}$ and hydrotalcite). The analysis was carried out using a Micromeritics Autochem 2950 instrument, supplied with streams of $\mathrm{NH}_{3}$ and $\mathrm{CO}_{2}$ (10 vol.\% in $\left.\mathrm{He}\right)$. Prior to the chemisorption step, each parent sample $(0.1 \mathrm{~g})$ was heated $\left(10^{\circ} \mathrm{C} \mathrm{min}^{-1}\right)$ under helium $\left(25 \mathrm{~cm}^{3} \mathrm{~min}^{-1}\right)$ up to $500^{\circ} \mathrm{C}$. In case of $\mathrm{NH}_{3}$ TPD analyses, the samples were cooled down to $180^{\circ} \mathrm{C}$, saturated with ammonia for $30 \mathrm{~min}\left(25 \mathrm{~cm}^{3} \mathrm{~min}^{-1}\right)$ and followed by removal of the physically adsorbed molecules by $\mathrm{He}$ stream $\left(25 \mathrm{~cm}^{3} \mathrm{~min}^{-1}\right)$ for $60 \mathrm{~min}$. Subsequently, the TPD curve was obtained by increasing the temperature with a heating ramp of $15^{\circ} \mathrm{C} \mathrm{min}^{-1}$ up to $500^{\circ} \mathrm{C}$ under $\mathrm{He}\left(25 \mathrm{~cm}^{3} \mathrm{~min}^{-1}\right)$, and maintaining this temperature for $30 \mathrm{~min}$. In the case of the $\mathrm{CO}_{2} \mathrm{TPD}$ analyses, the chemisorption was carried out at $50{ }^{\circ} \mathrm{C}$ for $30 \mathrm{~min}\left(50 \mathrm{~cm}^{3} \mathrm{~min}^{-1}\right)$. After the removal of physisorbed $\mathrm{CO}_{2}$ (by $\mathrm{He} 25 \mathrm{~cm}^{3} \mathrm{~min}^{-1}$ for $60 \mathrm{~min}$ ), the chemically absorbed $\mathrm{CO}_{2}$ was desorbed by heating the sample to $900{ }^{\circ} \mathrm{C}$ (heating rate of $15^{\circ} \mathrm{C} \mathrm{min}^{-1}$ ) under continuous flow of He gas $\left(25 \mathrm{~cm}^{3} \mathrm{~min}^{-1}\right.$ ) and keeping the final temperature for $30 \mathrm{~min}$. The concentration of desorbed ammonia and carbon dioxide in helium was recorded continuously by means of a thermal conductivity detector (TCD).

For catalyst re-activation, Bandelin DT 100 ultrasonic bath (frequency of $35 \mathrm{kHz}$, nominal power $320 \mathrm{~W}$ and heating $\left(30-80^{\circ} \mathrm{C}\right)$ ) and a normal UV lamp (Nail Art Gel 36W) were used for the ultrasonic irradiation and/or UV radiation, respectively.

\subsection{Catalytic experiments}

The catalytic properties of the prepared $\mathrm{TiO}_{2}$ samples were investigated in the aldol condensation of furfural with acetone. The properties of Mg-Al HTC and BEA zeolite samples were evaluated in comparative catalytic runs as well. The catalytic experiments were carried out in a $100 \mathrm{ml}$ stirred batch reactor (a round bottomed glass flask reactor with magnetic stirring) at $T=50^{\circ} \mathrm{C}$. For each experiment, $1 \mathrm{~g}$ of catalyst was taken and calcined, if necessary. Before the start of the catalytic runs at $50^{\circ} \mathrm{C}$, the weighed amount of a catalyst was mixed together with a stirred mixture consisting of $19.7 \mathrm{~g}$ acetone and $6.5 \mathrm{~g}$ of furfural (acetone/furfural molar ratio $5 / 1$ ), pre-heated to the desired reaction temperature and kept at the reaction temperature for $0-180 \mathrm{~min}$ under intensive stirring. In specially performed catalytic runs with $\mathrm{Mg}-\mathrm{Al} \mathrm{HTC}$ taken as a reference sample it was established that under the chosen reaction conditions the reaction was limited neither by external nor internal mass transfer by changing the stirring rate and catalyst particle size.
The samples of reaction mixtures were withdrawn from the reactor during the experiment at certain reaction times, filtered, and analyzed by an Agilent 7890A gas chromatograph equipped with a flame ionization detector (FID), using a HP 5 capillary column $(30 \mathrm{~m} / 0.32 \mathrm{~mm} \mathrm{ID} / 0.25 \mu \mathrm{m})$. The obtained products were identified based on standard reference compounds as well as additional GC-MS analyses.

Catalytic results of aldol condensation of furfural and acetone were described by conversion and selectivity parameters that were calculated as follows:

reactant conversion $(\mathrm{t})\left(\mathrm{mol}_{\mathrm{O}}\right)=100 \times\left(\right.$ reactant $_{t=0}-$ reactant $\left._{\mathrm{t}}\right) /$ reactant $_{t=0}$;

where selectivity to product $i=$ (mole of reactant converted to product $i) /($ total moles of reactant converted).

Carbon balance was monitored in all experiments as the total number of carbon atoms detected in each organic compound with Cn atoms (where $n=3,5,8, \ldots$, etc.) divided by the initial number of carbon atoms in $\mathrm{F}+\mathrm{Ac}$ feed:

Cbalance $(\%)=\left(\frac{3 \mathrm{~mol}_{3}+5 \mathrm{~mol}_{5}+\ldots n \operatorname{mol} C_{n}}{3 \mathrm{~mol}_{3(t=0)}+5 \mathrm{~mol}_{5(t=0)}}\right)$

\section{Result and discussion}

\subsection{Catalyst structure}

In the present study, anatase $\mathrm{TiO}_{2}$ was prepared by thermal hydrolysis of aqueous $\mathrm{TiOSO}_{4}$. According to Ahmed et al. [25], the $\mathrm{TiOSO}_{4}$ solution contains chains of $\mathrm{Ti}$ and $\mathrm{O}$ atoms which are interconnected by $\mathrm{SO}_{4}{ }^{2-}$ groups. The $-\mathrm{Ti}^{2+}-\mathrm{O}-\mathrm{Ti}^{2+}-\mathrm{O}-$ zigzag chains or oligomers have different chain lengths depending on the $\mathrm{TiOSO}_{4}$ concentration. At low concentrations, it has been shown that monomeric titanyl species with $2^{+}$charge, as well as dimers or trimmers are present. However, the number of monomeric titanyl decreases as the concentration of $\mathrm{TiOSO}_{4}$ increases. At high concentrations of titanyl, the percentage of monomeric form is negligible and titanium is mainly in the zigzag chains of $-\mathrm{Ti}^{2+}-\mathrm{O}-\mathrm{Ti}^{2+}-\mathrm{O}-$. The hydrolysis of urea generally proceeds in two steps (Eqs. (1) and (2)), the formation of ammonium cyanate $\left(\mathrm{NH}_{4} \mathrm{CNO}\right)$ being the rate determining step, with subsequent fast hydrolysis of the cyanate to ammonium carbonate, resulting in a $\mathrm{pH}$ value of 9 . However, in the synthesis of $\mathrm{TiO}_{2}$ in this study, the final $\mathrm{pH}$ for the suspension was about 7.02. The $\mathrm{pH}$ of $7-8$ is supposed to be suitable for the complete precipitation of Ti(IV) cations because the precipitation of Ti(IV) occurs even in an acidic or neutral aqueous medium.

$\mathrm{CO}\left(\mathrm{NH}_{2}\right)_{2} \rightarrow \mathrm{NH}_{4} \mathrm{CNO}$

$\mathrm{NH}_{4} \mathrm{CNO}+2 \mathrm{H}_{2} \mathrm{O} \rightarrow 2 \mathrm{NH}_{4}{ }^{+}+\mathrm{CO}_{3}{ }^{2-}$

Under these hydrolysis conditions $\mathrm{OH}$ groups attach to the $\mathrm{Ti}^{2+}-\mathrm{O}-\mathrm{Ti}^{2+}-\mathrm{O}-$ chains. The solubility of the partially hydrolysed $-\mathrm{Ti}^{2+}-\mathrm{O}-\mathrm{Ti}^{2+}-\mathrm{O}-$ chains is lower than that of their precursors. Consequently, these particles agglomerate to secondary and tertiary particles of titania. The hydrolysis of $\mathrm{TiOSO}_{4}$ results in the formation of white precipitate $3 \mathrm{TiO}_{2} \cdot 4 \mathrm{H}_{2} \mathrm{O}$ according to the following equation:

$$
\begin{aligned}
& \left(-\mathrm{Ti}^{2+}-\mathrm{O}-\mathrm{Ti}^{2+}-\mathrm{O}\right) \mathrm{n}+4 \mathrm{nOH} \rightarrow\left[-\mathrm{Ti}(\mathrm{OH})_{2}-\mathrm{O}-\mathrm{Ti}(\mathrm{OH})_{2}-\mathrm{O}-\right] \mathrm{n} \\
& \rightarrow 2 / 3 \mathrm{n}\left[3 \mathrm{TiO}_{2} \cdot 4 \mathrm{H}_{2} \mathrm{O}\right] \downarrow .
\end{aligned}
$$

The primary $3 \mathrm{TiO}_{2} \cdot 4 \mathrm{H}_{2} \mathrm{O}$ particles are produced in nonequilibrium conditions (high oversaturation, quick hydrolysis) and do not have a pronounced crystal shape. According to XRF measurement the as-prepared $\mathrm{TiO}_{2}$ material did not contain any residual sulfate groups, so their possible influence could be excluded from 


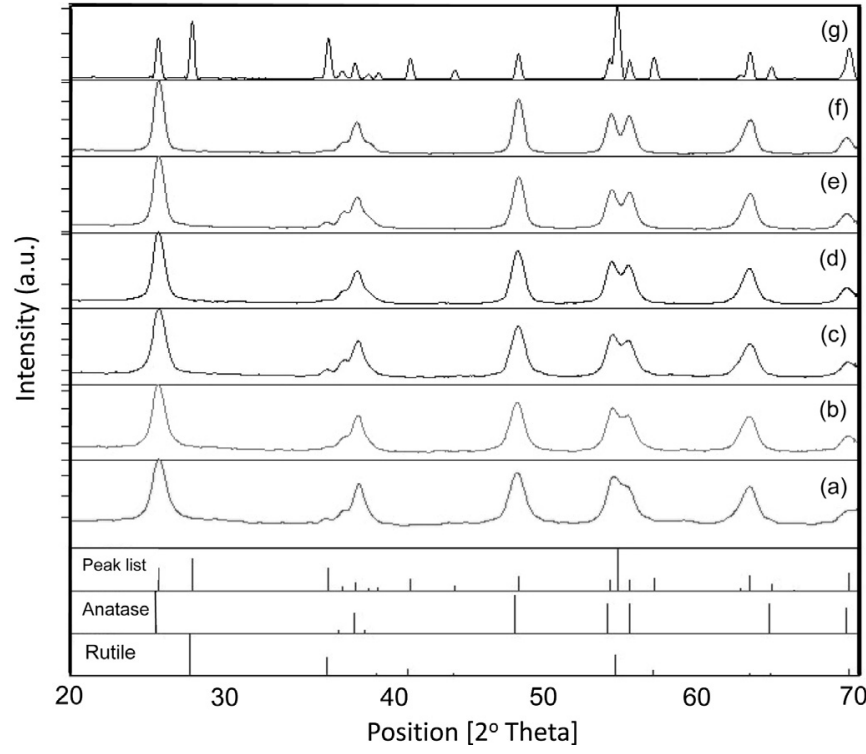

Fig. 1. XRD patterns of (a) $\mathrm{TiO}_{2}$ and $\mathrm{TiO}_{2}$ calcined at (b) 150 , (c) 250, (d) 350, (e) 450 , (f) 550 and (g) $900^{\circ} \mathrm{C}$.

further considering physico-chemical and catalytic properties of titania samples.

The XRD patterns shown in Fig. 1 indicated that the as-prepared powder (without further calcination) was already in the form of anatase $\mathrm{TiO}_{2}$. The reflections at 25.57, 38.08, 48.02, 54.20 and 62.90 corresponded to the (101), (004), (200), (105) and (204) planes of anatase (JCPDS file $n^{\circ}$. 21-1272). Upon calcination in the range of $300-550{ }^{\circ} \mathrm{C}$ (Fig. 1 ), the diffraction reflection intensities increased, indicating enhanced crystallinity of the anatase phase. Phase transformation from anatase to rutile occurred at $900{ }^{\circ} \mathrm{C}$ as shown in Fig. 1. The reflections at 27.73, 36.36, 41.51, 55.36, 56.89 and 62.98 corresponded to the (110), (101), (111), (211), (2 2 0$)$ and (002) planes of rutile with JCPDS file $\mathrm{n}^{\circ}$. 21-1276.

In most studies, $\mathrm{TiO}_{2}$ is synthesized by hydrolysis and condensation of titanium alkoxide precursors such as titanium isopropoxide and titanium butoxide. Using these alkoxide precursors normally results in amorphous $\mathrm{TiO}_{2}$ and thus subsequent calcination at elevated temperature $\left(300-500^{\circ} \mathrm{C}\right)$ has to be carried out to obtain anatase $\mathrm{TiO}_{2}[26,27]$. In addition, the resulting anatase $\mathrm{TiO}_{2}$ is susceptible to rutile transformation at relatively low temperatures $\left(500-700^{\circ} \mathrm{C}\right)[26-28]$. On $^{2}$ contrary, the XRD results in this study indicated that pure anatase was already formed without further calcination. In addition, the anatase-to-rutile transformation temperature was observed only at $900^{\circ} \mathrm{C}$, indicating the high thermal stability of the sample. The results suggested that thermal hydrolysis of aqueous $\mathrm{TiOSO}_{4}$ as presented in this study could be considered as a simple synthesis of thermally stable anatase $\mathrm{TiO}_{2}$. The hydrolysis of $\mathrm{TiOSO}_{4}$ has previously been used to prepare $\mathrm{TiO}_{2}$ supported on sintered glass by Hidalgo and Bahnemann [29]. Unfortunately, the crystallinity and thermal phase transformation of the as-prepared
Table 1

Crystallite size, phase content ${ }^{\mathrm{a}}$ of $\mathrm{TiO}_{2}$ nanoparticles calcined at different temperatures.

\begin{tabular}{lll}
\hline Catalysts & \multicolumn{2}{l}{ Crystal size $(\mathrm{nm})^{\mathrm{b}}$} \\
\cline { 2 - 3 } & Anatase $(101)$ plane & Rutile (110) plane \\
\hline $\mathrm{TiO}_{2}$ & 14.8 & \\
$\mathrm{TiO}_{2} 150$ & 14.8 & \\
$\mathrm{TiO}_{2} 250$ & 20.7 & \\
$\mathrm{TiO}_{2} 350$ & 17.2 & \\
$\mathrm{TiO}_{2} 450$ & 51.6 & \\
$\mathrm{TiO}_{2} 550$ & 68.4 & 629.4 \\
$\mathrm{TiO}_{2} 900$ & 203.8 & \\
\hline
\end{tabular}

a Calcination in the temperature range of $100-550{ }^{\circ} \mathrm{C}$ resulted in materials in the anatase form only, while calcination at $900{ }^{\circ} \mathrm{C}$ resulted in both anatase (68\%) and rutile (32\%) phases. $\mathrm{TiO}_{2} \mathrm{P} 25$ consists of anatase (87\%) and rutile (13\%).

b The estimation of crystal size was carried out using a Scherrer equation.

Table 2

Textural properties of the $\mathrm{TiO}_{2}$ samples calcined at different temperatures determine by $\mathrm{N}_{2}$ adsorption-desorption isotherms at $77 \mathrm{~K}$.

\begin{tabular}{llll}
\hline Catalysts & $\begin{array}{l}\text { Specific surface } \\
\left(\mathrm{m}^{2} / \mathrm{g}\right)^{\mathrm{a}}\end{array}$ & $\begin{array}{l}\text { Pore volume } \\
\left(\mathrm{cm}^{3} / \mathrm{g}\right)^{\mathrm{b}}\end{array}$ & Pore size $(\mathrm{nm})^{\mathrm{b}}$ \\
\hline $\mathrm{TiO}_{2}$ & 216 & 0.438 & 3 \\
$\mathrm{TiO}_{2} 150$ & 189 & 0.416 & 4.3 \\
$\mathrm{TiO}_{2} 250$ & 187 & 0.298 & 4.8 \\
$\mathrm{TiO}_{2} 350$ & 175 & 0.297 & 6.6 \\
$\mathrm{TiO}_{2} 450$ & 120 & 0.301 & 9.6 \\
$\mathrm{TiO}_{2} 550$ & 78 & 0.209 & 12.4 \\
$\mathrm{TiO}_{2} 900$ & 1.4 & - & - \\
$\mathrm{TiO}_{2}$ P25 & 77 & 0.136 & 3.4 \\
$\mathrm{Mg}-\mathrm{Al} \mathrm{HTC}$ & 179 & 0.188 & 3 \\
$\mathrm{H}-\mathrm{BEA}$ & 652 & $0.151^{\mathrm{c}}$ & $0.7^{\mathrm{c}}$ \\
\hline
\end{tabular}

a $\mathrm{BET}$ nitrogen isotherm at $77 \mathrm{~K}$

b BJH method adsorption branch.

c Micropore volume and BEA framework pore size.

material has not been discussed. Sakthivel et al. [30]. synthesised $\mathrm{TiO}_{2}$ via the forced hydrolysis of $\mathrm{TiOSO}_{4}$ at room temperature by using base hydrolysing agents $\left(\mathrm{NaOH}, \mathrm{Na}_{2} \mathrm{CO}_{3}\right.$ and $\left.\mathrm{NaHCO}_{3}\right)$. However, the $\mathrm{TiO}_{2}$ obtained therein was not as thermally stable as the one obtained in this work because $83 \mathrm{wt} . \%$ rutile was already found at $800^{\circ} \mathrm{C}$, while only $32 \mathrm{wt} . \%$ of rutile phase was observed after calcination at $900{ }^{\circ} \mathrm{C}$ in this study. All the other prepared $\mathrm{TiO}_{2}$ samples were in the anatase phase.

The results in Fig. 1 indicate that with increasing calcination temperature, the intensity of peaks increases and the diffraction peaks become sharper and narrower. This suggests the enhancement of the crystallinity which originated from the increment of the crystalline volume ratio due to the size enlargement of the nuclei [31]. The broad diffraction reflections observed for the $\mathrm{TiO}_{2}$ calcined at low temperature indicate the presence of crystalline particles with nanoscale size. In contrast, sharp diffraction peaks, indicating large crystallite size, can be seen for the sample calcined at high temperature. The crystallite size and phase composition of the $\mathrm{TiO}_{2}$ calcined at different temperatures are reported in Table 1. It can be clearly seen that an increase in the calcination temperature from

Table 3

$\mathrm{OH}$ groups weight percentage of $\mathrm{TiO}_{2}$ treated at different temperature and $\mathrm{TiO}_{2}-\mathrm{P} 25$ determined by TGA.

\begin{tabular}{|c|c|c|c|c|c|}
\hline Catalysts & Total weight loss, \% (w/w) & Humidity-physical adsorbed water \% (w/w) & $\mathrm{OH}$ weak \% (w/w) & $\mathrm{OH}$ strong $\%(\mathrm{w} / \mathrm{w})$ & $\mathrm{OH}$ total $\%(\mathrm{w} / \mathrm{w})$ \\
\hline $\mathrm{TiO}_{2}$ & 10.72 & 4.20 & 4.49 & 1.71 & 6.20 \\
\hline $\mathrm{TiO}_{2} 150$ & 7.77 & 2.42 & 3.38 & 1.71 & 5.09 \\
\hline $\mathrm{TiO}_{2} 250$ & 5.57 & 1.83 & 2.14 & 1.27 & 3.41 \\
\hline $\mathrm{TiO}_{2} 350$ & 3.94 & 1.24 & 1.61 & 0.78 & 2.39 \\
\hline $\mathrm{TiO}_{2} 450$ & 2.98 & 0.94 & 1.22 & 0.43 & 1.65 \\
\hline $\mathrm{TiO}_{2} 550$ & 2.21 & 0.71 & 0.86 & 0.28 & 1.14 \\
\hline $\mathrm{TiO}_{2} 900$ & 0.25 & 0.03 & 0.06 & 0.10 & 0.16 \\
\hline $\mathrm{TiO}_{2}-\mathrm{P} 25$ & 1.00 & 0.40 & 0.47 & 0.09 & 0.56 \\
\hline
\end{tabular}



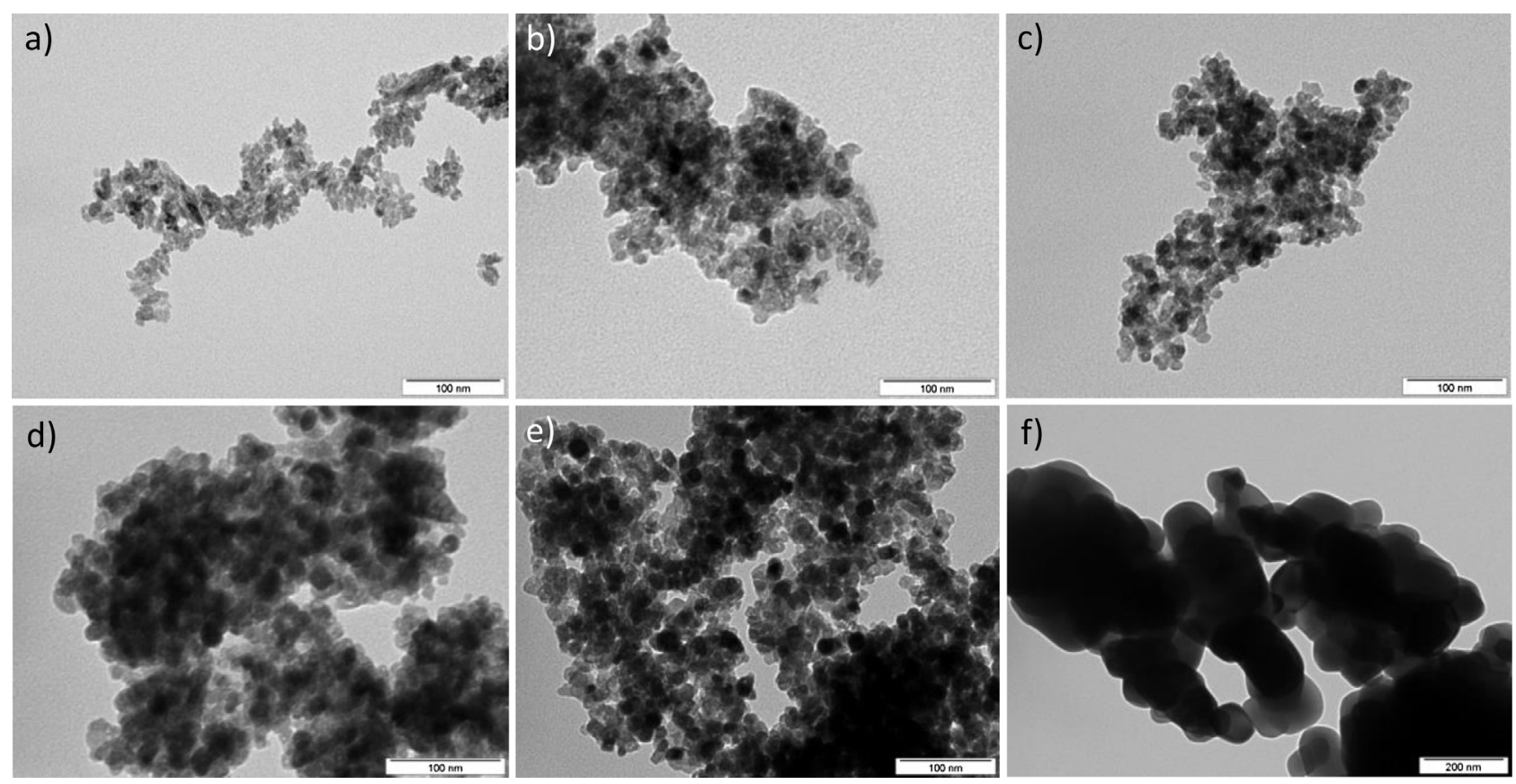

Fig. 2. TEM micrographs of $\mathrm{TiO}_{2}$ (a) and $\mathrm{TiO}_{2}$ calcined at (b) 250 , (c) 350, (d) 450, (e) 550 and (f) $900{ }^{\circ} \mathrm{C}$.

100 to $550{ }^{\circ} \mathrm{C}$ resulted in larger anatase crystallite size from 14.8 to $68.4 \mathrm{~nm}$. Raising the temperature further to $900^{\circ} \mathrm{C}$ produced a mixed phase of $68 \mathrm{wt} . \%$ anatase and $32 \mathrm{wt} . \%$ rutile with the anatase and rutile crystallite sizes of 203.8 and $629.4 \mathrm{~nm}$, respectively.

\subsection{Textural properties}

Based on the analysis of the experimental data from $\mathrm{N}_{2}$ physisorption, the increase of average crystal sizes as the calcination temperature increased was also accompanied with a significant decrease of BET specific surface area. According to Table 2, the specific surface area was drastically decreased from $216 \mathrm{~m}^{2} / \mathrm{g}$ (for $\mathrm{TiO}_{2}$ ) to $78 \mathrm{~m}^{2} / \mathrm{g}$ (for $\mathrm{TiO}_{2} 550$ ). Similar BET values and tendency to decrease with the growth of temperature were observed for titania materials in [32,33]. The variation in BET surface area was also accompanied by a reduction in pore volume values, which for the same samples decreased from 0.438 to $0.209 \mathrm{~cm}^{3} / \mathrm{g}(\approx 52 \%)$. These results may be correlated with the above discussed increase in crystal sizes with increasing calcination temperature, since according to literature [34-36], the crystallite growth of the anatase phase, along with the sintering and grain growth of the rutile phase, usually involve a reduction in the overall specific surface and pore volume. In contrast, pore size values showed an increasing trend with calcination temperature, likely associated with the transformation of anatase into rutile structure $[36,37]$. As soon as the anatase-to rutile transformation was occurred at $T=900^{\circ} \mathrm{C}$, BET surface of final sample decreased to $1.4 \mathrm{~m}^{2} / \mathrm{g}$ with hardly determined pore volume value. Additionally, the nitrogen adsorption-desorption isotherm of $\mathrm{TiO}_{2}$ samples calcined at $T \leq 550^{\circ} \mathrm{C}$ exhibited a noticeable adsorption at high relative pressures $\left(P / P_{0} \square 0.8\right)$ which corresponded to interparticle voids filling.

Compared to the textural properties showed by the commercial $\mathrm{TiO}_{2}$, the synthesized samples possess a higher pore volume for any calcination temperature, and a larger specific surface for calcination temperatures below $250^{\circ} \mathrm{C}$. Likewise, an important improvement is observed with respect to $\mathrm{TiO}_{2} \mathrm{P} 25$ pore size $(3.4 \mathrm{~nm})$, increasing especially for the samples calcined above $350^{\circ} \mathrm{C}(6.6-12.4 \mathrm{~nm})$. Regarding the textural properties of $\mathrm{Mg}-\mathrm{Al} \mathrm{HTC}$ and $\mathrm{H}-\mathrm{BEA}$, both materials show lower pore volume and pore size than the synthesized titania materials. Nevertheless, Beta zeolite has much larger specific surface and smaller pore size due to its microporous framework, what is expected to lead to significant differences in the catalytic activity.

\subsection{TEM images}

The size of the primary particles was dependent upon the calcination temperature as observed from the TEM images (Fig. 2c and d). The particle size was $14.8 \mathrm{~nm}$ at $100^{\circ} \mathrm{C}$ (Fig. 2c) and increased to $51.6 \mathrm{~nm}$ at $450{ }^{\circ} \mathrm{C}$ (Fig. 2d) what is in accordance to results published elsewhere [32,33] The particle size increased further to 203.8 and $629.4 \mathrm{~nm}$ for anatase and rutile, respectively, due to calcination at $900^{\circ} \mathrm{C}$. The results of TEM analysis of $\mathrm{TiO}_{2}$ samples are in agreement with the XRD results.

\subsection{FTIR}

FTIR spectra of $\mathrm{TiO}_{2}$ samples calcined at different temperatures are shown in Fig. 3. The bands observed in the range of $3100-3400 \mathrm{~cm}^{-1}$ can be attributed to the stretching vibrations of structural hydroxyl groups, which is very similar to that observed for the hydrotalcites [8]. The intensity of this band decreases with the increase in calcination temperature from 100 to $550^{\circ} \mathrm{C}$ until its total disappearance at $900^{\circ} \mathrm{C}$ (anatase and rutile phase mixture). The bands observed at $1440 \mathrm{~cm}^{-1}$ can be associated with the presence of $-\mathrm{OH}$ groups related to the bound water or free water adsorbed on the surface of $\mathrm{TiO}_{2}$ [12]. This band is present only for the samples thermally treated at temperatures below $250^{\circ} \mathrm{C}$ (Fig. 3). Also, in analogy with the hydrotalcites, the peak at $1632 \mathrm{~cm}^{-1}$ could be attributed to water molecules which results in a bending vibration in the $\mathrm{TiO}_{2}$ mesopores [8].

The high hydration level of samples calcined at low temperatures is probably also responsible for broad absorption bands in the spectral range of $1000-1380 \mathrm{~cm}^{-1}$, assigned to the $\delta(\mathrm{Ti}-\mathrm{O}-\mathrm{H})$ deformation vibrations [38]. Data from Fig. 3 clearly show that the intensity of the peaks associated with the presence of hydroxyl groups decreased (or the peaks even disappeared) when increas- 


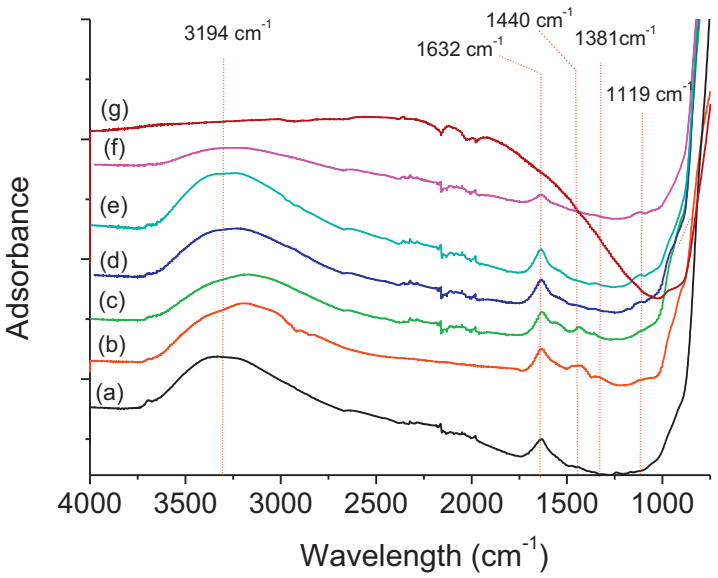

Fig. 3. FTIR spectra of $\mathrm{TiO}_{2} \mathrm{P} 25$ (a), $\mathrm{TiO}_{2}$ (b) and $\mathrm{TiO}_{2}$ calcined at (c) 250, (d) 350, (e) 450, (f) 550 and (g) $900^{\circ} \mathrm{C}$.

ing the temperature in the range of $100-900^{\circ} \mathrm{C}$, especially at $900^{\circ} \mathrm{C}$ there is no evidence of hydroxyl groups being present at all.

FTIR spectra of commercial $\mathrm{TiO}_{2}$ P25 shows the absence of the band at $1440 \mathrm{~cm}^{-1}$ due to the presence of $-\mathrm{OH}$ groups related to the bound water what makes this material similar to calcined $\mathrm{TiO}_{2}$ samples prepared in the study. Nevertheless, $\mathrm{TiO}_{2} \mathrm{P} 25$ contains both structural hydroxyl groups and water molecules in the mesopores, what is confirmed by the presence of IR bands at 3100-3400 and $1632 \mathrm{~cm}^{-1}$, respectively.

\subsection{TGA/DTG}

The number of surface $\mathrm{OH}$ groups can be determined by various methods such as infrared spectroscopy [39-42], ion-exchange reaction [41], titration procedures [42-45] and nuclear magnetic resonance $[46,47]$. In addition, thermal gravimetric analysis is often used to estimate the number of $\mathrm{OH}$ groups on the surface as it is a simple and fast method compared to the other techniques $[40,43,47,48]$. The TGA-DTG peaks and data obtained from the thermal analysis studies of the $\mathrm{TiO}_{2}$ samples are presented in Fig. 4 and Table. 3 . Total weight loss of the samples with anatase structure decreased from $10.72 \%$ to $0.25 \%$ as the calcination temperature increases to $900^{\circ} \mathrm{C}$ (Fig. 4a, Table 3). The course of the TGA curves (Fig. 4a) exhibited a gradual weight loss process with four main events that were reflected as peaks in the DTG curves (Fig. 4b). According to Mueller et al [48]. the weight loss of hydroxylated $\mathrm{TiO}_{2}$ samples in the $30-120^{\circ} \mathrm{C}$ range is due to the physically adsorbed water. In line with this, for all $\mathrm{TiO}_{2}$ samples calcined at different temperatures, the first step involved the loss of adsorbed water that occurred between ambient temperature and about $75-120^{\circ} \mathrm{C}$ and decreased from 4.20 to $0.034 \%$ with the increase in calcination temperature. The second weight loss was observed in the range of $150-300^{\circ} \mathrm{C}$ (Fig. 4b). It decreased from $4.49 \%$ for as-prepared $\mathrm{TiO}_{2}$ sample to $0.86 \%$ for $\mathrm{TiO}_{2} 500$ and $0.06 \%$ for $\mathrm{TiO}_{2} 900$. Samples thermally treated at $T=100-350^{\circ} \mathrm{C}$ had also an additional weight loss at ca. $450-550^{\circ} \mathrm{C}$, while another wide signal in the range of $750-809^{\circ} \mathrm{C}$ was present on DTG curves, especially for the samples calcined at high temperature. Taking into account FTIR data (Fig. 3), it can be concluded that DTG signals in the range of 150-350 and $450-550^{\circ} \mathrm{C}$ are related to the dehydroxylation of $\mathrm{TiO}_{2}$ surface and prove the presence of weakly/medium and strongly bonded $\mathrm{OH}$-groups, respectively. On the other hand, when combined with the XRD data, the TGA results indicate that the high temperature signal above $700^{\circ} \mathrm{C}$ on DTG curve can be attributed to the anatase to rutile phase transformation.
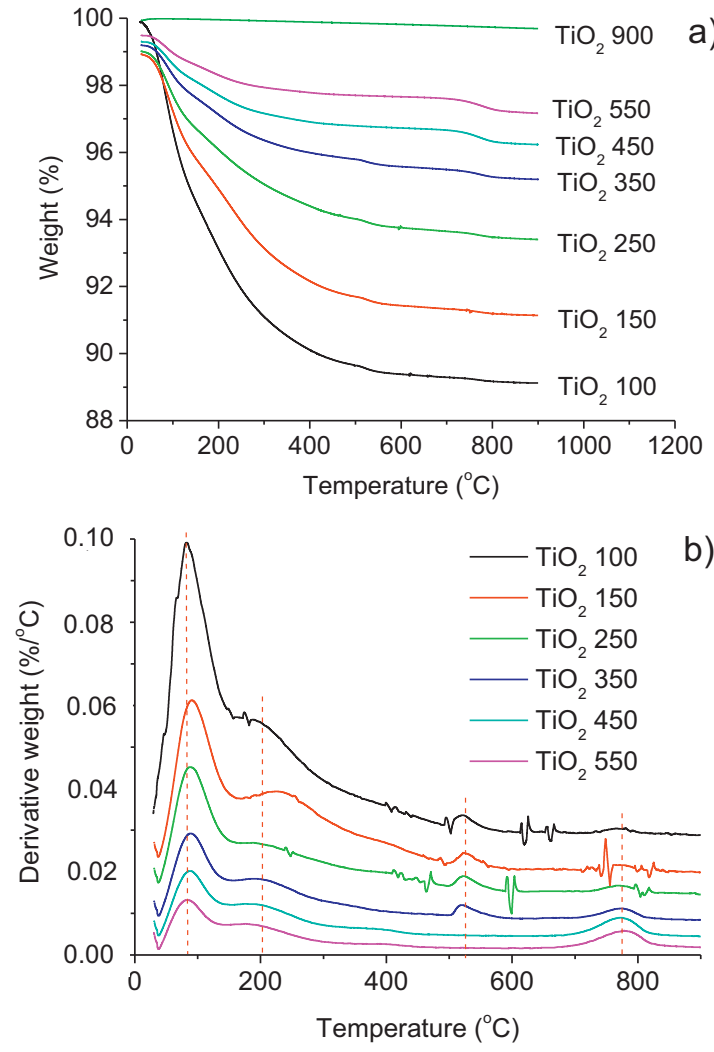

Fig. 4. TGA/DTG curves of $\mathrm{TiO}_{2}$.

Table 4

Results from the $\mathrm{CO}_{2}$ and $\mathrm{NH}_{3}$ temperature programmed desorption of the studied samples.

\begin{tabular}{lllll}
\hline Catalysts & \multicolumn{4}{l}{ Acid-basic properties } \\
\cline { 2 - 5 } & $\begin{array}{l}\mathrm{NH}_{3} \text { uptake } \\
(\mu \mathrm{mol} / \mathrm{g})\end{array}$ & $\begin{array}{r}\mathrm{T}_{\max }\left({ }^{\circ} \mathrm{C}\right) \mathrm{CO}_{2} \text { uptake } \\
(\mu \mathrm{mol} / \mathrm{g})\end{array}$ & $T_{\max }\left({ }^{\circ} \mathrm{C}\right)$ \\
\hline $\mathrm{TiO}_{2} 500$ & 256 & 274 & 344 & 184 \\
$\mathrm{TiO}_{2} \mathrm{P} 25$ & 140 & 286 & 223 & 183 \\
$\mathrm{Mg}-\mathrm{Al} \mathrm{HTC}$ & - & - & 836 & 180 \\
$\mathrm{H}-\mathrm{BEA}$ & 572 & 278 & - & - \\
\hline
\end{tabular}

\subsection{TPD of $\mathrm{NH}_{3}$ and $\mathrm{CO}_{2}$}

Fig. 5 shows the $\mathrm{CO}_{2}(5 \mathrm{a})$ and $\mathrm{NH}_{3}(5 \mathrm{~b})$ temperature programmed desorption (TPD) of the synthesized $\mathrm{TiO}_{2}$ material after being calcined at $500^{\circ} \mathrm{C}$. In order to evaluate its acid-basic properties, TPD curves of the reference basic material, such as hydrotalcite, and acid catalyst, like Beta zeolite, are also represented. Likewise, this figure includes the TPD results obtained from the commercial $\mathrm{TiO}_{2} \mathrm{P} 25$. The overall measured amount and strength of acid/basic sites of the samples are summarized in Table 4. It is worthy to note that $\mathrm{CO}_{2} / \mathrm{NH}_{3}$ adsorption was performed after an outgassing treatment at $500^{\circ} \mathrm{C}$ under helium. Consequently, some artefacts may occur altering the features of the samples with respect to the aldol condensation conditions.

The reactive adsorption of $\mathrm{CO}_{2}$ over metal-oxide materials (Fig. 5a), leads to the formation of carbonates species which are desorbed at different temperatures [49-52]. Thus, bicarbonate anions, whose formation is associated with the presence of surface hydroxyl groups, desorb typically in the range $90-110^{\circ} \mathrm{C}$. Hence, these species are usually attributed to the interaction of $\mathrm{CO}_{2}$ with sites of weak basic strengths. The peaks at $190-230^{\circ} \mathrm{C}$ correspond to the desorption of the bidentate carbonates, formed 

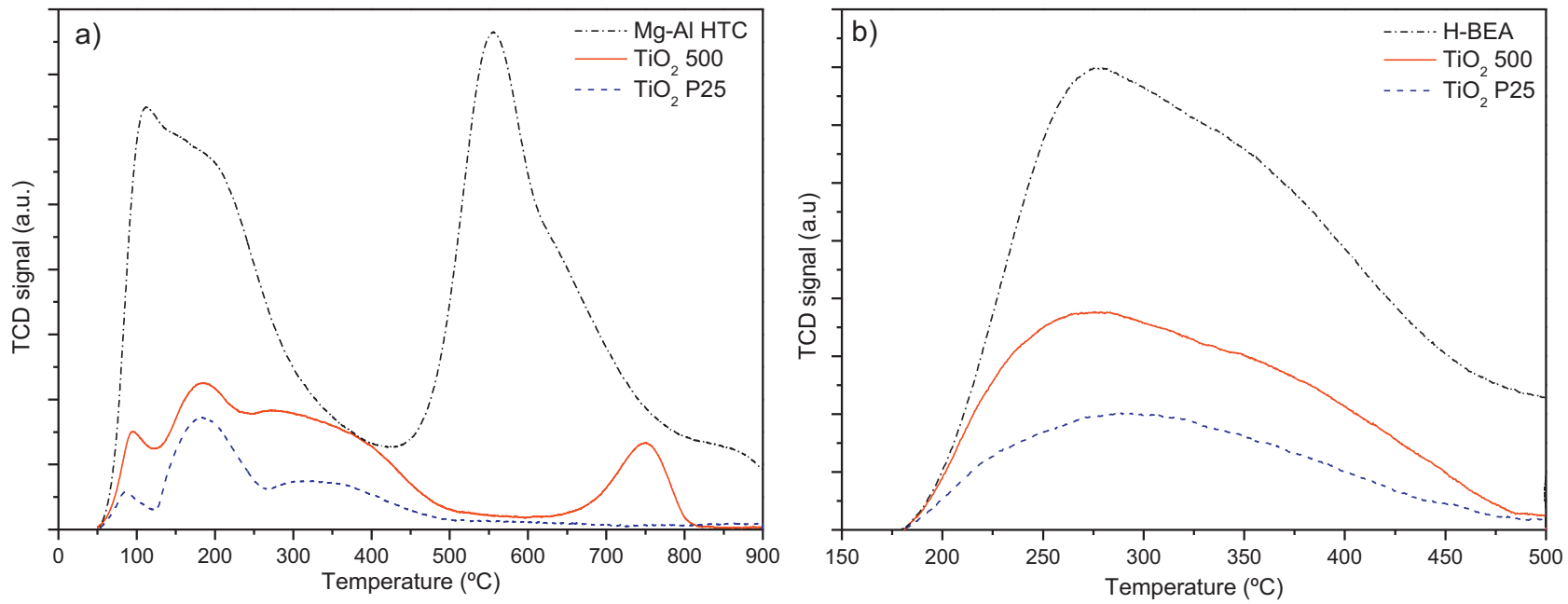

Fig. 5. $\mathrm{CO}_{2}$ (a) and $\mathrm{NH}_{3}$ (b) temperature programmed desorption curves of synthesized $\mathrm{TiO}_{2} 500$ and the commercial catalysts: $\mathrm{TiO}_{2} \mathrm{P} 25, \mathrm{Mg}-\mathrm{Al}$ hydrotalcite (Mg-Al $\mathrm{HTC}$ ) and Beta zeolite (H-BEA).
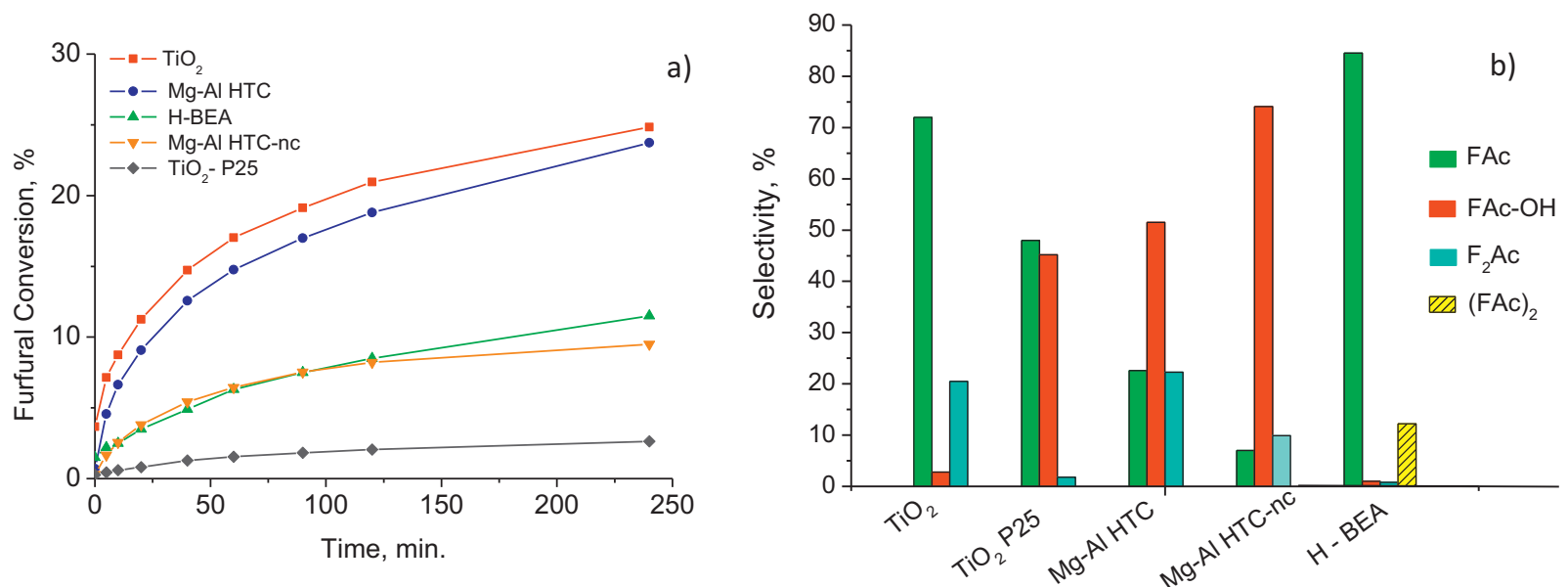

Fig. 6. Properties of different solids as catalysts for aldol condensation of furfural and acetone. (a). Furfural conversion. (b). Selectivity to reaction products at $t=240$ min.
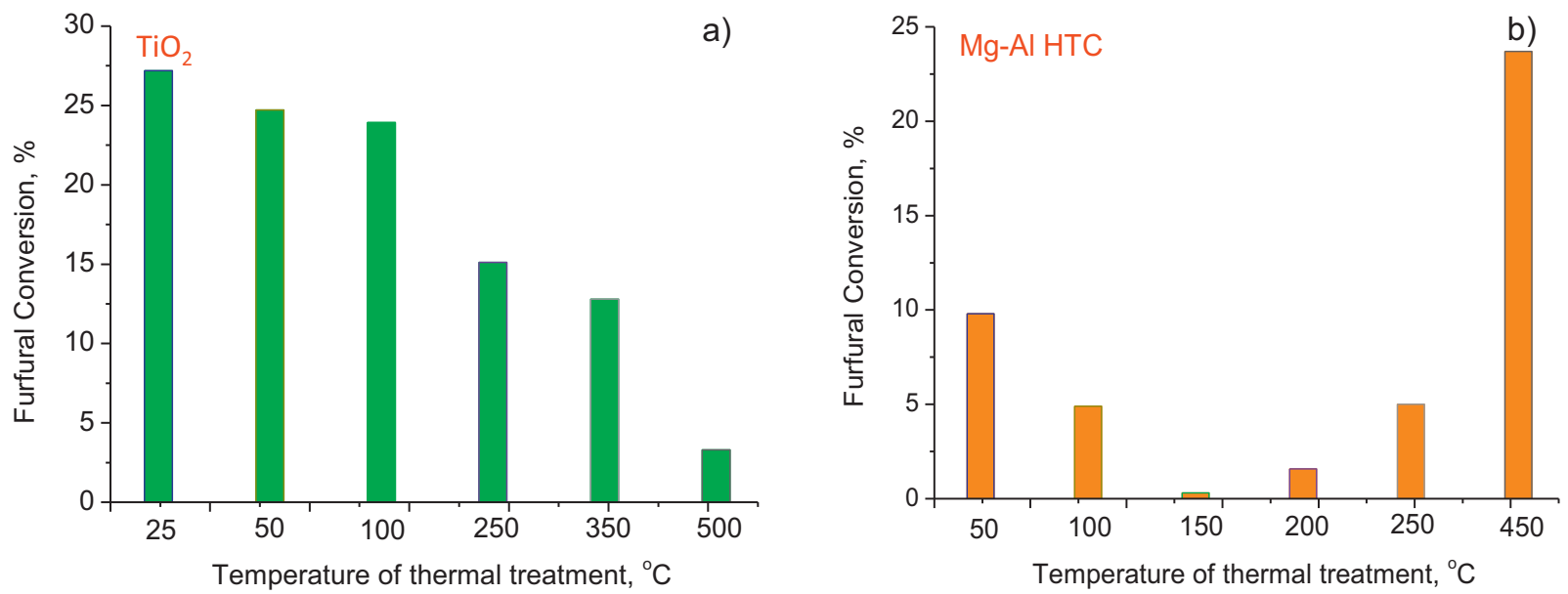

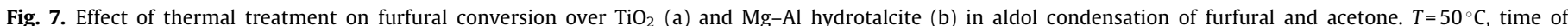
experiment $-240 \mathrm{~min}$.

on metal-oxide pairs and related to basic sites of medium strength. Likewise, monodentate species formed on low-coordination oxygen anions appears around $320^{\circ} \mathrm{C}$ and are related to the presence of strong basic sites. On the other hand, according to previous works $[53,54]$, the $\mathrm{CO}_{2}$ desorbed above $500^{\circ} \mathrm{C}$ arises from the remaining carbonates that were not removed during the calcination and 


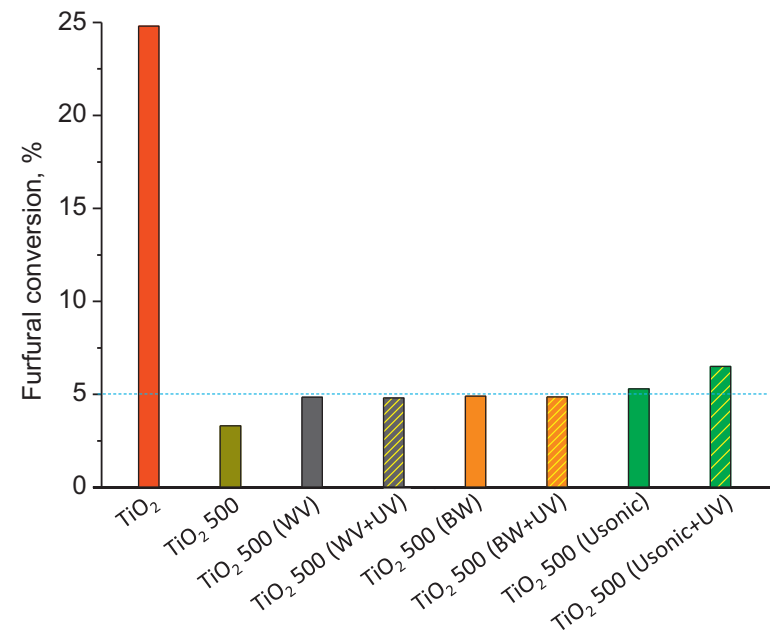

Fig. 8. Comparison of catalytic properties of $\mathrm{TiO}_{2}$ samples before and after calcination with.

Table 5

Effect of pre-rehydration with aqueous acetone mixture (10 wt.\% of water) on the properties of inorganic solids in aldol condensation of furfural and acetone.

\begin{tabular}{ll}
\hline Catalyst & Furfural Conversion, \% \\
\hline $\mathrm{HTC}-450$ & 23.7 \\
$\mathrm{HTC}-450\left(\mathrm{H}_{2} \mathrm{O}\right)$ & 98.9 \\
$\mathrm{HTC}-50$ & 9.8 \\
$\mathrm{HTC}-50\left(\mathrm{H}_{2} \mathrm{O}\right)$ & 0 \\
$\mathrm{TiO}_{2}-50$ & 24.7 \\
$\mathrm{TiO}_{2}-50\left(\mathrm{H}_{2} \mathrm{O}\right)$ & 0 \\
$\mathrm{TiO}_{2}-500$ & 3.3 \\
$\mathrm{TiO}_{2}-500\left(\mathrm{H}_{2} \mathrm{O}\right)$ & 4.9 \\
\hline
\end{tabular}

outgassing steps $\left(500^{\circ} \mathrm{C}\right)$. Thus, these residual carbonates were not considered to be accounted for as basic sites (Table 4), since, they were not derived from chemisorbed $\mathrm{CO}_{2}$, which was confirmed by a blank test.

The total amount of basic sites determined by the integration of the TPD curves for both titania samples were considerably lower than the value showed by $\mathrm{Mg}-\mathrm{Al}$ HTC $\left(836 \mu \mathrm{molg}^{-1}\right)$. The profile of hydrotalcite $\mathrm{CO}_{2}$ TPD is in accordance with the well-known basic character of this material, and, equally, with the important presence of $\mathrm{CO}_{3}{ }^{2-}$ species acting as compensation anions in the interlayer region (peak $\approx 550^{\circ} \mathrm{C}$ ). Titania samples exhibited similar $\mathrm{CO}_{2}$ TPD profiles with three different desorption peaks at $90^{\circ} \mathrm{C}, 185^{\circ} \mathrm{C}$ and $290-320^{\circ} \mathrm{C}$, due to the presence of basic sites of different strengths (bicarbonate, bidentate and monodentate carbonates, respectively). In both cases, the maximum desorption rate corresponded to the bidentate species $\left(185^{\circ} \mathrm{C}\right)$, indicating the prevalence of intermediate-strength basic sites. Nevertheless, for all the adsorbed carbonates the synthesized $\mathrm{TiO}_{2} 500$ showed a higher contribution than the commercial $\mathrm{TiO}_{2} \mathrm{P} 25$, reaching overall values of basic sites of 344 and $223 \mu \mathrm{mol} \mathrm{g}^{-1}$, respectively (Table 4).

According to $\mathrm{NH}_{3}$ TPD method, H-BEA zeolite possessed the highest acid character with the total concentration of acid sites as high as $572 \mu \mathrm{mol} \mathrm{g}^{-1}$ (Fig. 5b and Table 4). Nevertheless, titania samples under the study also exhibited reasonable acidity. Indeed, the presence of different acid sites in $\mathrm{TiO}_{2}$ was reported repeatedly [55-58]. It was suggested that the Lewis and Brønsted acid sites responsible for the catalytic activity of these materials could be generated from adsorbed water molecules [57]. Among two titania samples, the $\mathrm{TiO}_{2} 500$ uptakes a higher amount of ammonia $\left(256 \mu \mathrm{mol} \mathrm{g}^{-1}\right)$ than the $\mathrm{TiO}_{2}$ P25 $\left(140 \mu \mathrm{mol} \mathrm{g}^{-1}\right)$, implying a greater presence of active acid sites [57] in the synthesized material. The shape of $\mathrm{NH}_{3}$ TPD curves (Fig. 5b) also indicate that both H-BEA and titania materials have more than one kind of acid sites which could differ in their strength. This observation is in agreement with results from [58] where $\mathrm{NH}_{3}$ TPD signal for $\mathrm{TiO}_{2}$ was observed in the range of $T=100-500^{\circ} \mathrm{C}$. Additionally it was suggested that the acid strength of $\mathrm{TiO}_{2}$ may be affected by the formation of titania suboxides (coordinatively unsaturated Ti cations) under the influence of elevated temperatures [55].

To summarize, the obtained TPD results reveal that the synthesized titania sample $\left(\mathrm{TiO}_{2} 500\right)$ possess a higher amount of both base and acid sites than the commercial titania material, with a similar basic/acid strength. This fact may is of importance for the studied process as the number and accessibility of these active sites determine the activity and selectivity of aldol condensation reactions.

\subsection{Catalysis}

\subsubsection{Aldol condensation of furfural and acetone with different samples}

Fig. 6 depicts the results on the catalytic performance of different catalysts in aldol condensation of furfural with acetone. In all cases furfural conversion increased with the increase in experiment duration (Fig. 6a) but it also showed an obvious dependence on the type of material used. Hydrotalcites with different chemical composition are solids which are most often used as heterogeneous catalysts for aldol condensation. Fig. 6a shows that furfural conversion over uncalcined Mg-Al HTC was about $10 \%$ after $240 \mathrm{~min}$ of the reaction. The calcination of this material at $450{ }^{\circ} \mathrm{C}$ resulted in a significant increase in its activity in the reaction so that furfural conversion reached $24 \%$. According to previous studies, such increase in activity in base-catalyzed reactions observed for calcined $\mathrm{Mg}-\mathrm{Al}$ materials is due to the decomposition of carbonate groups during the heat treatment of the as-prepared samples and formation of strong basic sites [15]. The presence of strong basicity in calcined $\mathrm{Mg}-\mathrm{Al}$ mixed oxides was confirmed by $\mathrm{CO}_{2}-\mathrm{TPD}$ (see above). Previously we have shown [14] that zeolites can also be used as acid catalysts for aldol condensation. Indeed, Fig. $6 a$ shows that furfural conversion in the presence of BEA zeolite is $12 \%$ after 240 min of the reaction. Experiments performed with $\mathrm{TiO}_{2}$ samples as catalysts showed that catalytic performance of these materials substantially depends on the method of their preparation. The industrially available commercial $\mathrm{TiO}_{2}$ exhibited a very low activity in the reaction, furfural conversion being only $3 \%$ after $240 \mathrm{~min}$. In contrast, $\mathrm{TiO}_{2}$ samples prepared in the present study 
Table 6

Different treatments applied for calcined $\mathrm{TiO}_{2}-500$ sample.

\begin{tabular}{|c|c|c|c|}
\hline $\mathrm{N}^{\circ}$ & Sample name & Sample preparation & Catalytic procedure \\
\hline 1 & $\mathrm{TiO}_{2} 500(\mathrm{WV})$ & $\begin{array}{l}\text { Treatment with water vapors for } 5 \mathrm{~h} \text {, filtration } \\
\text { and drying at } 100^{\circ} \mathrm{C} \text { for } 12 \mathrm{~h}\end{array}$ & Usual \\
\hline 2 & $\mathrm{TiO}_{2} 500(\mathrm{WV}+\mathrm{UV})$ & $\begin{array}{l}\text { Treatment with water vapors for } 5 \mathrm{~h} \text {, filtration } \\
\text { and drying at } 100^{\circ} \mathrm{C} \text { for } 12 \mathrm{~h}\end{array}$ & $\begin{array}{l}\text { UV irradiation of the catalyst for } 1 \mathrm{~h} \text { before the } \\
\text { catalytic experiment }\end{array}$ \\
\hline 3 & $\mathrm{TiO}_{2} 500(\mathrm{BW})$ & $\begin{array}{l}\text { Treatment with boiling water for } 5 \mathrm{~h} \text {, filtration } \\
\text { and drying at } 100^{\circ} \mathrm{C} \text { for } 12 \mathrm{~h}\end{array}$ & Usual \\
\hline 4 & $\mathrm{TiO}_{2} 500(\mathrm{BW}+\mathrm{UV})$ & $\begin{array}{l}\text { Treatment with boiling water for } 5 \mathrm{~h} \text {, filtration } \\
\text { and drying at } 100^{\circ} \mathrm{C} \text { for } 12 \mathrm{~h}\end{array}$ & $\begin{array}{l}\text { UV irradiation of the catalyst for } 1 \mathrm{~h} \text { before the } \\
\text { catalytic experiment }\end{array}$ \\
\hline 5 & $\mathrm{TiO}_{2}$ 500(USonic) & $\begin{array}{l}\text { Treatment in a sonicator for } 3 \mathrm{~h} \text {, filtration and } \\
\text { drying at } 100^{\circ} \mathrm{C} \text { for } 12 \mathrm{~h}\end{array}$ & Usual \\
\hline 6 & $\mathrm{TiO}_{2}$ 500(USonic + UV) & $\begin{array}{l}\text { Treatment in a sonicator for } 3 \mathrm{~h} \text {, filtration and } \\
\text { drying at } 100^{\circ} \mathrm{C} \text { for } 12 \mathrm{~h}\end{array}$ & $\begin{array}{l}\text { UV irradiation of the catalyst for } 1 \mathrm{~h} \text { before the } \\
\text { catalytic experiment }\end{array}$ \\
\hline
\end{tabular}

possessed activity in the reaction which was comparable with that observed for calcined $\mathrm{Mg}-\mathrm{Al}$ sample. Fig. 6a shows that furfural conversion over nanosized $\mathrm{TiO}_{2}$ reached $25 \%$ after $240 \mathrm{~min}$. The presented results show that, depending upon the preparation method, $\mathrm{TiO}_{2}$ material may have sufficient amount of active centers active in aldol condensation furfural with acetone to compete with the well-known materials used in the reaction. The composition of the aldol condensation reaction products allowed us to assess the importance of different active sites which are present in $\mathrm{TiO}_{2}$.

Selectivity to the main reaction products after $240 \mathrm{~min}$ of the reaction are shown in Fig. 6b. FAc-OH was the most abundant compound observed over as-prepared $\mathrm{Mg}-\mathrm{Al} \mathrm{HTC}$. An increase in the activity of this catalyst (which was achieved by its calcination) decreased selectivity to FAc-OH and increased the selectivity to the products formed either by its dehydration (yielding FAc) or interaction with another furfural molecule (affording $\mathrm{F}_{2} \mathrm{Ac}$ ). FAc-OH, as the initial product of aldol condensation, was easily dehydrated in the presence of strong acid centers of H-BEA to form FAc with selectivity exceeding $80 \%$. According to [14,19], the presence (FAc) $)_{2}$, which is formed by the dimerization of FAc, is a distinctive feature of aldol condensation of furfural with acetone in the presence of acidic catalysts. Characterization of the $\mathrm{TiO}_{2}$ materials by the TPD method using $\mathrm{NH}_{3}$ and $\mathrm{CO}_{2}$ indicated that these solids exhibited amphoteric character, i.e. they possessed both basic and acidic sites. Thus, the question arised which centers were responsible for the aldol condensation activity of $\mathrm{TiO}_{2}$ materials.

Fig. $6 \mathrm{~b}$ shows that $(\mathrm{FAc})_{2}$ was absent in reaction products formed in the presence of $\mathrm{TiO}_{2}$ catalysts regardless of their origin. Consequently, it can be deduced that the reaction between furfural and acetone to aldol condensation products over $\mathrm{TiO}_{2}$ occurred with the participation of basic rather than acidic sites. However, the effect of acidic centers on the composition of the reaction products cannot be completely excluded. Fig. $6 \mathrm{~b}$ shows that even for the commercial $\mathrm{TiO}_{2}$ sample possessing low activity, the selectivity to FAc, i.e. a dehydrated reaction product, was significantly higher in comparison with the more active $\mathrm{Mg}-\mathrm{Al} \mathrm{HTC}$. Moreover, in the case of the more active $\mathrm{TiO}_{2}$, i.e. the nanosized $\mathrm{TiO}_{2}$, the selectivity to the main dehydrated product, FAc, reached $72 \%$. The strength of basic sites in $\mathrm{Mg}-\mathrm{Al} \mathrm{HTC}$ is higher than of those in $\mathrm{TiO}_{2}$ (Fig. 6a), but the ability of the former to promote dehydration reaction is lower at the same conversion level. Therefore it can be proposed that the enhanced selectivity to FAc observed for $\mathrm{TiO}_{2}$ is due to the presence of acid sites. In summary, the catalytic results suggest that the properties of the acid sites in $\mathrm{TiO}_{2}$ were not sufficient to promote aldol condensation or dimerization yielding $(\mathrm{FAc})_{2}$, but were sufficient to dehydrate FAc-OH to FAc.

\subsubsection{The properties of thermally treated $\mathrm{TiO}_{2}$ and $\mathrm{Mg}-\mathrm{Al} \mathrm{HTC}$ samples}

Since nanosized $\mathrm{TiO}_{2}$ exhibited good activity in aldol condensation of furfural with acetone, the catalytic performance of this material was investigated in more detail. Fig. 7 shows the effect of calcination temperature on the furfural conversion over $\mathrm{TiO}_{2}$.

The increase in the temperature of thermal pretreatment of $\mathrm{TiO}_{2}$ resulted in a gradual decrease in its activity in aldol condensation. Furfural conversion over the as-prepared $\mathrm{TiO}_{2}$ reached $27 \%$ after $240 \mathrm{~min}$, but even a gentle drying at $100^{\circ} \mathrm{C}$ decreased the furfural conversion to $24 \%$. Subsequently, furfural conversion decreased to $15 \%$ and as low as $3 \%$ after 240 min of the reaction when the $\mathrm{TiO}_{2}$ catalyst was pretreated (calcined) at $T=250^{\circ} \mathrm{C}$ and $500^{\circ} \mathrm{C}$, respectively. Considering the changes of physico-chemical characteristics of the $\mathrm{TiO}_{2}$ sample in the dependence on its thermal pretreatment allows understanding the reasons of the observed changes in the catalytic performance.

Tables 1 and 2 provide evidence that as a result of thermal pretreatment of $\mathrm{TiO}_{2}$ sample in the range from room temperature to $350^{\circ} \mathrm{C}$, the crystal size of $\mathrm{TiO}_{2}$ gradually increased whereas the BET surface area reduced. Moreover, the increase in the temperature of the thermal pretreatment from room temperature to $350^{\circ} \mathrm{C}$ caused an increase in pore volume of the resulting samples. Therefore, the observed reduction of the catalytic activity with the increasing pretreatment temperature is unlikely to be solely associated with the found changes in the textural properties of $\mathrm{TiO}_{2}$ materials. On the other hand, TGA data show that with increasing calcination temperature an irreversible decrease of weight loss due to dehydration and surface dehydroxylation were observed. Moreover, TGA experiments show that both the amount of surface hydroxyl groups which were removed at $T \geq 100^{\circ} \mathrm{C}$ and the amount of physisorbed water removed at lower temperatures decreased when the pretreatment temperature was subsequenlty increased. The results of thermal analysis thus clearly showed that even a small increase in the pretreatment temperature may influence the external surface properties of $\mathrm{TiO}_{2}$, despite the catalysts have similar textural chacracteristics. Data in Fig. 8 suggest that samples with the largest amount of both physically adsorbed water and hydroxyl groups which, according to TGA, are removed at $T=100-300^{\circ} \mathrm{C}$ exhibited the highest activity in aldol condensation. Combined with TPD results, it can be concluded that basic sites in $\mathrm{TiO}_{2}$ catalyzing aldol condensation consist of weak hydroxyl groups which are probably formed at the defect sites of anatase nanocrystals. However, the positive effect of physically adsorbed water on the catalytic activity of inorganic oxides in aldol condensation cannot be completely excluded.

In comparative experiments, we have investigated the effect of mild heat treatment on the catalytic activity of Mg-Al HTC in aldol condensation. Fig. $7 \mathrm{~b}$ depicts that the increase in the pretreatment temperature from 50 to $150^{\circ} \mathrm{C}$ decreased furfural conversion from 10 down to $0.3 \%$. In this temperature range only the removal of physically adsorbed water from HTC was possible, so the catalytic activity of the as-prepared $\mathrm{Mg}-\mathrm{Al} \mathrm{HTC}$ in its carbonate form could be attributed to the presence of water physically bound to the surface of HTC layered structure. The presented example of the dependence of HTC properties on its thermal pretreatment is 
aimed to illustrate that hydrated layered materials could possess activity in basic catalyzed reactions even not being calcined. This is, however, outside the topic of the present study and hence we will discuss this research topic in our forthcoming publication. However, the comparison of catalytic results for uncalcined HTC and titania materials show definite similarities in their behavior: their activity in aldol condensation could be attributed to the presence of water molecules either as adsorbed species in mesoporous space or as terminal hydroxyls attached to the defective sites of a crystalline framework.

\subsubsection{Re-activation of calcined $\mathrm{TiO}_{2}$}

Taking into account above suggestion, either the excessive hydroxylation or hydration of $\mathrm{TiO}_{2}$ surface seems to be of great importance for the aldol condensation of furfural with acetone to take place. As a result of thermal pretreatment, $\mathrm{TiO}_{2}$ samples lost both surface water and hydroxyl groups and as a consequence their activity in the reaction decreased. Such behavior of $\mathrm{TiO}_{2}$ catalysts could have serious negative implications for practical applicability of these materials as catalysts for aldol condensation of furfural with acetone, as thermal regeneration of catalysts after the reaction would inevitably result in a significant decrease in their activity in following catalytic runs. Hence, the next step of the present study was concerned with evaluating the possibility to rehydrate thermally treated $\mathrm{TiO}_{2}$ materials. For these experiments, we have used our own method developed during studies of the in situ rehydration of calcined $\mathrm{Mg}-\mathrm{Al}$ mixed oxides. According to this method, the calcined catalyst is contacted with acetone containing known amount of water for a specific time, followed by furfural addition to start aldol condensation reaction. Table 5 evidences that such in situ rehydration method could be really effective, since the pretreatment of calcined $\mathrm{Mg}-\mathrm{Al}$ mixed oxide with aqueous acetone mixture containing $10 \%$ of water resulted in a dramatic increase in the activity of rehydrated $\mathrm{Mg}-\mathrm{Al}$ hydrotalcites in aldol condensation. The observed improvement in the catalytic activity is caused by the transformation of Lewis basic sites which are present in calcined Mg-Al material to Brønsted basic sites which possess higher activity in different organic reactions in comparison with Lewis basic sites [19,23].

However, the contact of Mg-Al HTC heated at $T=50^{\circ} \mathrm{C}$ with the same aqueous acetone mixture completely suppressed the catalytic activity of the catalyst. A similar result was also obtained when the same treatment procedure was used for $\mathrm{TiO}_{2}$ sample thermally treated at $T=50^{\circ} \mathrm{C}$ : the activity of this overhydrated sample in aldol condensation was negligible. These results show that the nature of active sites catalyzing aldol condensation in calcined $\mathrm{Mg}-\mathrm{Al}$ mixed oxide and in as-prepared Mg-Al HTC is different and that the active sites in $\mathrm{TiO}_{2}$ which possess the activity in aldol condensation mostly resemble those which are present in the as-prepared $\mathrm{Mg}$-Al hydrotalcites. In both cases the nature of such sites could be related to either hydration or hydroxylation of the external surface of these inorganic materials.

The unsuccessful attempts on the direct hydroxylation of calcined $\mathrm{TiO}_{2}$ with aqueous acetone solution indicate that the agglomeration of $\mathrm{TiO}_{2}$ nanoparticles due to calcination and the related decrease in BET surface could be contributing factor to the decrease in catalytic activity. To de-agglomerate the $\mathrm{TiO}_{2}$ particles in the calcined $\mathrm{TiO}_{2} 500$ sample and re-hydroxylation its surface, several methods were used (Table 6). In these experiments the possible influence of UV irradiation on catalytic activity of the prepared samples was investigated; such additional pre-treatment of $\mathrm{TiO}_{2}$ materials would result in the further growth of their catalytic activity provided that photocatalytic effect took place.

Fig. 8 shows that all the methods used resulted in a slight but obvious increase in the catalytic activity of the treated catalysts. The experiment relying on ultrasonic pretreatment of the catalyst was the most successful, ensuring an increase in furfural conversion from $3.3 \%$ for $\mathrm{TiO}_{2}-500$ to $5.3-6.5 \%$ for the treated catalysts after $240 \mathrm{~min}$ of the reaction. Nonetheless, compared with the uncalcined $\mathrm{TiO}_{2}$ catalyst the activity of the re-activated calcined $\mathrm{TiO}_{2}$ materials is significantly lower. Moreover, the results show that the effect of UV irradiation is not apparent, i.e. the photocatalytic properties of the $\mathrm{TiO}_{2}$ surface are clearly not important for the studied reaction. So, despite the promising catalytic properties of $\mathrm{TiO}_{2}$ materials as catalysts for aldol condensation of furfural and acetone the question of their regeneration allowing at least maintaining of their initial activity is still open to discussion and could be considered as a challenge for future studies.

\section{Conclusions}

In the present work, thermal hydrolysis of $\mathrm{TiOSO}_{4}$ aqueous solution has successfully been used to prepare nanocrystalline anatase $\mathrm{TiO}_{2}$. The method provides an advantage over the hydrolysis of titanium alkoxide precursors, as the crystalline anatase is readily formed in a one-step process. The presence of rutile phase was found at $900^{\circ} \mathrm{C}$ in only $32 \mathrm{wt} . \%$ suggesting a higher thermal stability of the nanosized $\mathrm{TiO}_{2}$ compared with that prepared from alkoxide precursors.

The catalytic performance of the prepared $\mathrm{TiO}_{2}$ sample in aldol condensation of furfural with acetone was evaluated and compared with those for Mg-Al hydrotalcites and BEA zeolite. These experiments showed that uncalcined $\mathrm{TiO}_{2}$ possesses good activity which could be competitive with that reported for other inorganic solids. The absence of (FAc) 2 compound in the reaction products confirmed that the aldol condensation between aldehyde and ketone over $\mathrm{TiO}_{2}$ proceeded with the participation of basic rather than acidic sites. However, the presence of acidic sites could be advantage for more facile dehydration of condensation products as indicated by the comparison of the product distribution over $\mathrm{TiO}_{2}$ and hydrotalcites. The calcination of $\mathrm{TiO}_{2}$ results, however, in a decrease in its catalytic activity due to extensive dehydration and surface dehydroxylation, as well as due to the change in textural properties resulting in a decrease in the amount of accessible active sites. The re-hydration/re-hydroxylation of calcined $\mathrm{TiO}_{2}$ sample by different methods resulted in only a slight increase in the catalytic activity.

\section{Acknowledgements}

The authors acknowledge the Czech Science Foundation for the financial support (Center of Excellence-P106/12/G015). The project (P106/12/G015) is being carried out in the UniCRE center (CZ.1.05/2.1.00/03.0071) in the Research Institute of Inorganic Chemistry whose infrastructure was used. The authors also wish to thank to P. Ryšánek, K. Černá and P. Kovář for XRD, FTIR measurements and chemicals supply, respectively.

\section{References}

[1] IEA, World Energy Outlook, 2014, IEA.

[2] J., Goldemberg, T.B., Johansson, D., Anderson, U.N.D., Programme, U.N.D.o. Economic, S., Affairs, W.E. Council, World Energy Assessment: Overview: 2004 Update, United Nations Development Programme, Bureau for Development Policy, 2004.

[3] S. Tojo, T. Hirasawa, Research Approaches to Sustainable Biomass Systems, Elsevier Science, 2013.

[4] C. Sánchez, Lignocellulosic residues: biodegradation and bioconversion by fungi, Biotechnol. Adv. 27 (2009) 185-194.

[5] F. Talebnia, D. Karakashev, I. Angelidaki, Production of bioethanol from wheat straw: an overview on pretreatment, hydrolysis and fermentation, Bioresour. Technol. 101 (2010) 4744-4753.

[6] D. Kubička, I. Kubičková, J. Čejka, Application of molecular sieves in transformations of biomass and biomass-derived feedstocks, Catal. Rev. 55 (2013) 1-78 
[7] P. Mäki-Arvela, T. Salmi, B. Holmbom, S. Willför, D.Y. Murzin, Synthesis of Sugars by Hydrolysis of Hemicelluloses: a review, Chem. Rev. 111 (2011) $5638-5666$.

[8] P.A. Zapata, J. Faria, M. Pilar Ruiz, D.E. Resasco, Condensation/hydrogenation of biomass-derived oxygenates in water/oil emulsions stabilized by nanohybrid catalysts, Top. Catal. 55 (2012) 38-52.

[9] M. Mosher, Organic chemistry. Sixth edition (Morrison, Robert Thornton; Boyd, Robert Neilson), J. Chem. Educ. 69 (1992) A305.

[10] D.S. Kemp, F. Vellaccio, Organic Chemistry, Worth Publishers, 1980.

[11] A.S. Ndou, N. Plint, N.J. Coville, Dimerisation of ethanol to butanol over solid-base catalysts, Appl. Catal. A: Gen. 251 (2003) 337-345.

[12] D. Tichit, M. Naciri Bennani, F. Figueras, R. Tessier, J. Kervennal, Aldol condensation of acetone over layered double hydroxides of the meixnerite type, Appl. Clay Sci. 13 (1998) 401-415.

[13] C.J. Barrett, J.N. Chheda, G.W. Huber, J.A. Dumesic, Single-reactor process for sequential aldol-condensation and hydrogenation of biomass-derived compounds in water, Appl. Catal. B: Environ. 66 (2006) 111-118.

[14] O. Kikhtyanin, V. Kelbichová, D. Vitvarová, M. Kubů, D. Kubička, Aldol condensation of furfural and acetone on zeolites, Catal. Today 227 (2014) $154-162$.

[15] L. Hora, V. Kelbichová, O. Kikhtyanin, O. Bortnovskiy, D. Kubička, Aldol condensation of furfural and acetone over MgAl layered double hydroxides and mixed oxides, Catal. Today 223 (2014) 138-147.

[16] D.P. Debecker, E.M. Gaigneaux, G. Busca, Exploring, tuning, and exploiting the basicity of hydrotalcites for applications in heterogeneous catalysis, Chem. A Eur. J. 15 (2009) 3920-3935.

[17] C. Xu, Y. Gao, X. Liu, R. Xin, Z. Wang, Hydrotalcite reconstructed by in situ rehydration as a highly active solid base catalyst and its application in aldo condensations, RSC Adv. 3 (2013) 793-801.

[18] S. Abelló, D. Vijaya-Shankar, J. Pérez-Ramírez, Stability, reutilization, and scalability of activated hydrotalcites in aldol condensation, Appl. Catal. A: Gen. 342 (2008) 119-125

[19] O. Kikhtyanin, D. Kubička, J. Čejka, Toward understanding of the role of Lewis acidity in aldol condensation of acetone and furfural using MOF and zeolite catalysts, Catal. Today 243 (2015) 158-162.

[20] A. Fujishima, T.N. Rao, D.A. Tryk, Titanium dioxide photocatalysis, J. Photochem. Photobiol. C: Photochem. Rev. 1 (2000) 1-21.

[21] A. Di Paola, M. Bellardita, L. Palmisano, Brookite, the least known $\mathrm{TiO}_{2}$ photocatalyst, Catalysts 3 (2013) 36 .

[22] Y. Ohama, D. Van Gemert, Application of Titanium Dioxide Photocatalysis to Construction Materials: State-of-the-Art Report of the RILEM Technical Committee 194-TDP, Springer, Netherlands, 2011.

[23] L. Hora, O. Kikhtyanin, L. Čapek, O. Bortnovskiy, D. Kubička, Comparative study of physico-chemical properties of laboratory and industrially prepared layered double hydroxides and their behavior in aldol condensation of furfural and acetone, Catal. Today Part B 241 (2015) 221-230.

[24] M.A. Behnajady, H. Eskandarloo, N. Modirshahla, M. Shokri, Investigation of the effect of sol-gel synthesis variables on structural and photocatalytic properties of $\mathrm{TiO}_{2}$ nanoparticles, Desalination 278 (2011) 10-17.

[25] H.F.M. Ahmed, A. Kjekshus, Syntheses and crystal structures of titanium oxide sulfates, Acta Chem. Scand. (1996) 275.

[26] N. Wetchakun, S. Phanichphant, Effect of temperature on the degree of anatase-rutile transformation in titanium dioxide nanoparticles synthesized by the modified sol-gel method, Curr. Appl. Phys. 8 (2008) 343-346.

[27] M.A. Behnajady, H. Eskandarloo, N. Modirshahla, M. Shokri, Sol-gel low-temperature synthesis of stable anatase-type $\mathrm{TiO}_{2}$ nanoparticles under different conditions and its photocatalytic activity, Photochem. Photobiol. 87 (2011) 1002-1008.

[28] M.E. Simonsen, E.G. Søgaard, Sol-gel reactions of titanium alkoxides and water: influence of $\mathrm{pH}$ and alkoxy group on cluster formation and properties of the resulting products, J. Sol-Gel Sci. Technol. 53 (2010) 485-497.

[29] M.C. Hidalgo, D. Bahnemann, Highly photoactive supported $\mathrm{TiO}_{2}$ prepared by thermal hydrolysis of TiOSO4: optimisation of the method and comparison with other synthetic routes, Appl. Catal. B: Environ. 61 (2005) 259-266.

[30] S. Sakthivel, M.C. Hidalgo, D.W. Bahnemann, S.U. Geissen, V. Murugesan, A. Vogelpohl, A fine route to tune the photocatalytic activity of TiO2, Appl. Catal. B: Environ. 63 (2006) 31-40.

[31] C.S. Barrett, T.B. Massalski, Structure of Metals: Crystallographic Methods, Principles, and Data, McGraw-Hill, 1966

[32] P. Wen, C. Cai, H. Zhong, L. Hao, X. Xu, A simple way to synthesize anatase with high thermal stability, J. Mater. Sci. 50 (2015) 5944-5951.

[33] S. Ngamta, N. Boonprakob, N. Wetchakun, K. Ounnunkad, S. Phanichphant, B. Inceesungvorn, A facile synthesis of nanocrystalline anatase TiO2 from $\mathrm{TiOSO}_{4}$ aqueous solution, Mater. Lett. 105 (2013) 76-79.

[34] S. Bakardjieva, J. Šubrt, V. Štengl, M.J. Dianez, M.J. Sayagues, Photoactivity of anatase-rutile $\mathrm{TiO}_{2}$ nanocrystalline mixtures obtained by heat treatment of homogeneously precipitated anatase, Appl. Catal. B: Environ. 58 (2005) 193-202.
[35] K.-N.P. Kumar, K. Keizer, A.J. Burggraaf, T. Okubo, H. Nagamoto, Synthesis and textural properties of unsupported and supported rutile $\left(\mathrm{TiO}_{2}\right)$ membranes, J. Mater. Chem. 3 (1993) 923-929.

[36] M.S.P. Francisco, V.R. Mastelaro, Inhibition of the anatase-rutile phase transformation with addition of $\mathrm{CeO} 2$ to $\mathrm{CuO}_{-} \mathrm{TiO}_{2}$ system: Raman spectroscopy, X-ray diffraction, and textural studies, Chem. Mater. 14 (2002) 2514-2518.

[37] K.J.A. Raj, B. Viswanathan, Effect of surface area, pore volume and particle size of P25 titania on the phase transformation of anatase to rutile, Ind. J. Chem. A 48 (2009) 1378.

[38] T. Bezrodna, G. Puchkovska, V. Shymanovska, J. Baran, H. Ratajczak, IR-analysis of $\mathrm{H}$-bonded $\mathrm{H} 2 \mathrm{O}$ on the pure $\mathrm{TiO}_{2}$ surface, J. Mol. Struct. 700 (2004) 175-181.

[39] M.A. Ramos, M.H. Gil, E. Schacht, G. Matthys, W. Mondelaers, M.M. Figueiredo Physical and chemical characterisation of some silicas and silica derivatives, Powder Technol. 99 (1998) 79-85.

[40] T.M.H. Costa, M.R. Gallas, E.V. Benvenutti, J.A.H. da Jornada, Infrared and thermogravimetric study of high pressure consolidation in alkoxide silica gel powders, J. Non-Cryst. Solids 220 (1997) 195-201.

[41] J.A.R. Van Veen, F.T.G. Veltmaat, G. Jonkers, A method for the quantitative determination of the basic, acidic, and total surface hydroxy content of $\mathrm{TiO}_{2}, \mathrm{~J}$. Chem. Soc. Chem. Commun. (1985) 1656-1658.

[42] J.J. Fripiat, J. Uytterhoeven, Hydroxyl content in silica gel aerosil, J. Phys. Chem. 66 (1962) 800-805.

[43] G.E. Kellum, R.C. Smith, Determination of water, silanol, and strained siloxane on silica surfaces, Anal. Chem. 39 (1967) 341-345.

[44] B. Ohtani, Y. Okugawa, S.I. Nishimoto, T. Kagiya, Photocatalytic activity of $\mathrm{TiO}_{2}$ powders suspended in aqueous silver nitrate solution. Correlation with pH-dependent surface structures, J. Phys. Chem. 91 (1987) 3550-3555.

[45] C.G. Armistead, A.J. Tyler, F.H. Hambleton, S.A. Mitchell, J.A. Hockey, Surface hydroxylation of silica, J. Phys. Chem. 73 (1969) 3947-3953.

[46] V.M. Bermudez, A proton nuclear magnetic resonance technique for determining the surface hydroxyl content of hydrated silica gel, J. Phys. Chem. 74 (1970) 4160-4161.

[47] R.K. Gilpin, M.E. Gangoda, M. Jaroniec, Preparation and characterization of silica-carbon hybrids, Carbon 35 (1997) 133-139.

[48] R. Mueller, H.K. Kammler, K. Wegner, S.E. Pratsinis, OH surface density of $\mathrm{SiO} 2$ and $\mathrm{TiO}_{2}$ by thermogravimetric analysis, Langmuir 19 (2003) 160-165.

[49] M. Di Serio, M. Ledda, M. Cozzolino, G. Minutillo, R. Tesser, E. Santacesaria, Transesterification of soybean oil to biodiesel by using heterogeneous basic catalysts, Ind. Eng. Chem. Res. 45 (2006) 3009-3014

[50] C.O. Veloso, C.N. Pérez, B.M. de Souza, E.C. Lima, A.G. Dias, J.L.F. Monteiro, C.A. Henriques, Condensation of glyceraldehyde acetonide with ethyl acetoacetate over Mg, Al-mixed oxides derived from hydrotalcites, Microporous Mesoporous Mater. 107 (2008) 23-30.

[51] J.I. Di Cosimo, V.K. Diíez, M. Xu, E. Iglesia, C.R. Apesteguía, Structure and surface and catalytic properties of Mg-Al Basic oxides, J. Catal. 178 (1998) 499-510.

[52] M. Bolognini, F. Cavani, D. Scagliarini, C. Flego, C. Perego, M. Saba, Heterogeneous basic catalysts as alternatives to homogeneous catalysts: reactivity of $\mathrm{Mg} / \mathrm{Al}$ mixed oxides in the alkylation of m-cresol with methanol, Catal. Today 75 (2002) 103-111.

[53] S. Abelló, F. Medina, D. Tichit, J. Pérez-Ramírez, X. Rodríguez, J.E. Sueiras, P. Salagre, Y. Cesteros, Study of alkaline-doping agents on the performance of reconstructed $\mathrm{Mg}-\mathrm{Al}$ hydrotalcites in aldol condensations, Appl. Catal. A: Gen. 281 (2005) 191-198

[54] W. Yang, Y. Kim, P.K.T. Liu, M. Sahimi, T.T. Tsotsis, A study by in situ techniques of the thermal evolution of the structure of a $\mathrm{Mg}-\mathrm{Al}-\mathrm{CO} 3$ layered double hydroxide, Chem. Eng. Sci. 57 (2002) 2945-2953.

[55] M. Englisch, A. Jentys, J.A. Lercher, Structure sensitivity of the hydrogenation of crotonaldehyde over Pt/SiO2 and Pt/TiO2, J. Catal. 166 (1997) 25-35.

[56] T. Kataoka, J.A. Dumesic, Acidity of unsupported and silica-supported vanadia, molybdena, and titania as studied by pyridine adsorption, J. Catal. 112 (1988) $66-79$

[57] A. Mantilla, G. Ferrat, A. López-Ortega, E. Romero, F. Tzompantzi, M. Torres, E. Ortíz-Islas, R. Gómez, Catalytic behavior of sulfated $\mathrm{TiO}_{2}$ in light olefins oligomerization, J. Mol. Catal. A: Chem. 228 (2005) 333-338.

[58] M. Watanabe, Y. Aizawa, T. Iida, R. Nishimura, H. Inomata, Catalytic glucose and fructose conversions with $\mathrm{TiO}_{2}$ and $\mathrm{ZrO}_{2}$ in water at $473 \mathrm{~K}$ : relationship between reactivity and acid-base property determined by TPD measurement Appl. Catal. A: Gen. 295 (2005) 150-156. 